\title{
Centennial scale climate instabilities in a wet early Holocene West
}

\section{African monsoon}

\author{
Syee Weldeab, ${ }^{1,2}$ David W. Lea, ${ }^{1}$ Ralph R. Schneider, ${ }^{3}$ and Nils Andersen ${ }^{4}$ \\ Received 6 September 2007; accepted 13 November 2007; published 21 December 2007.
}

[1] A Holocene Gulf of Guinea record of riverine runoff, based on $\mathrm{Ba} / \mathrm{Ca}$ in tests of a shallow-dwelling planktic foraminifer, and sea surface temperature (SST), based on $\mathrm{Mg} / \mathrm{Ca}$, reveals centennial-scale instabilities in West African monsoon (WAM) precipitation and eastern equatorial Atlantic (EEA) thermal conditions. The long-term Holocene climate trend is characterized by a warm and wet early-mid Holocene and gradual drying and cooling during the late Holocene. Superimposed on this trend are numerous centennial scale drops in precipitation during the early-mid Holocene. The greatest declines in early Holocene monsoon precipitation were accompanied by significant SST cooling in the EEA and correlate with drops in air temperature over Greenland and fresh water outbursts into the North Atlantic (NA). This observation suggests that early Holocene climate instabilities in the NA were closely linked to changes in the WAM. The strong imprint of NA events in summer monsoon precipitation suggests that these events were not confined to winter-time. The late Holocene does not show large amplitude changes in riverine runoff at the centennial level. The relatively stable late Holocene conditions likely reflect a weakening and stabilization of the monsoon system, probably due to diminished influence of the NA region due to a reduction in ice sheet. Citation: Weldeab, S., D. W. Lea, R. R. Schneider, and N. Andersen (2007), Centennial scale climate instabilities in a wet early Holocene West African monsoon, Geophys. Res. Lett., 34, L24702, doi:10.1029/2007GL031898.

\section{Introduction}

[2] It is well known that Holocene West African climate underwent dramatic changes, as evidenced by several records from marine [deMenocal et al., 2000; Kuhlmann et al., 2004; Weldeab et al., 2005, 2007] and terrestrial climate archives [Lezine and Cazet, 2005; Shanahan et al., 2006]. These records suggest humid conditions during the early and middle Holocene followed by a dry late Holocene. The long term Holocene climate trend follows low latitude northern hemisphere summer insolation and shows a close link to EEA SST (SST) [Weldeab et al., 2005, 2007]. However, our understanding of centennial-scale West African climate conditions, the nature of climate transitions

\footnotetext{
${ }^{1}$ Department of Earth Science and Marine Science Institute, University of California, Santa Barbara, California, USA.

${ }^{2}$ Now at Leibniz-Institut für Meereswissenschaften an der Universität Kiel, Kiel, Germany.

${ }^{3}$ Institut für Geowissenschaften, Universität Kiel, Germany.

${ }^{4}$ Leibniz-Labor für Altersbestimmung und Isotopenforschung, Universität Kiel, Kiel, Germany.
}

Copyright 2007 by the American Geophysical Union. 0094-8276/07/2007GL031898\$05.00 during the Holocene (abrupt versus gradual), and the climate stability of the west African monsoon (WAM) and its linkage to northern high latitude climate [NGRIP members, 2004] remains fragmentary due to lack of a high-resolution and well dated proxy records for past West African precipitation changes.

[3] Here we a present centennial-scale precipitation history of the WAM, using a marine sediment core MD03$2707\left(02^{\circ} 30.11^{\prime} \mathrm{N}, 09^{\circ} 23.68^{\prime} \mathrm{E}\right.$, water depth $\left.1295 \mathrm{~m}\right)$ recovered from the eastern part of the Gulf of Guinea, EEA (Figure 1). The core material covers the last 155,000 years of West African climate history [Weldeab et al., 2007]. In this study we exclusively focus on high resolution Holocene climate variability, with average sampling rates of 30 years in the late Holocene and 50 years in early and middle Holocene. Detailed discussion of long term climate trend and its relationship with global monsoon records is provided by Weldeab et al. [2007]. Under modern conditions, the hydrology above MD03-2707 site is strongly influenced by riverine runoff of the Niger and Sanaga rivers, covering a catchment area of $\sim 2,400,000 \mathrm{~km}^{2}$ and annual riverine fresh water input of $\sim 277 \mathrm{~km}^{3}$ into the eastern part of the Gulf of Guinea (Figure 1). Accordingly, sea surface salinity (SSS) over the site is very low, varying between 30 and 32 practical salinity unit (psu) throughout July to September and between 26 and 32 psu from October to January in the $25 \mathrm{~m}$ of the upper water column [Levitus, 1994]. Because the riverine runoff profoundly affects the hydrology above the site (Figure 1), we hypothesize that significant changes in the precipitation over the drainage basins, which integrate a large part of WAM area, would be manifested in the oxygen isotope and trace element compositions of sea surface water which is archived in tests of shallow-dwelling planktonic foraminifers that accumulate in marine sediment.

[4] We analyzed $\mathrm{Ba} / \mathrm{Ca}, \mathrm{Mg} / \mathrm{Ca}$, and oxygen isotope composition $\left(\delta^{18} \mathrm{O}\right)$ in tests of planktic foraminifera Globigerinoides ruber $(250-300 \mu \mathrm{m})$ pink variety that dwells in the upper $30 \mathrm{~m}$ of the water column and its shell chemistry reflects mixed layer conditions [Weldeab et al., 2007]. A detailed analytical description is provided in the auxiliary material ${ }^{1}$ (AM). We utilize $\mathrm{Ba} / \mathrm{Ca}$ in $G$. ruber tests as direct proxy for riverine runoff variation because riverine runoff is enriched in dissolved $\mathrm{Ba}$ relative to sea water [Weldeab et al., 2007] and Ba uptake in planktic foraminiferal calcite linearly varies with $\mathrm{Ba}$ concentration in sea water [Lea and Spero, 1994]. To obtain a semi-quantitative estimate of runoff-induced SSS variations, as indicated by the $\mathrm{Ba} / \mathrm{Ca}$, we calculated the $\mathrm{Ba} / \mathrm{Ca}_{\text {foram }}$-SSS relationship

\footnotetext{
${ }^{1}$ Auxiliary material files are available in the HTML. doi:10.1029/ 2007GL031898.
} 


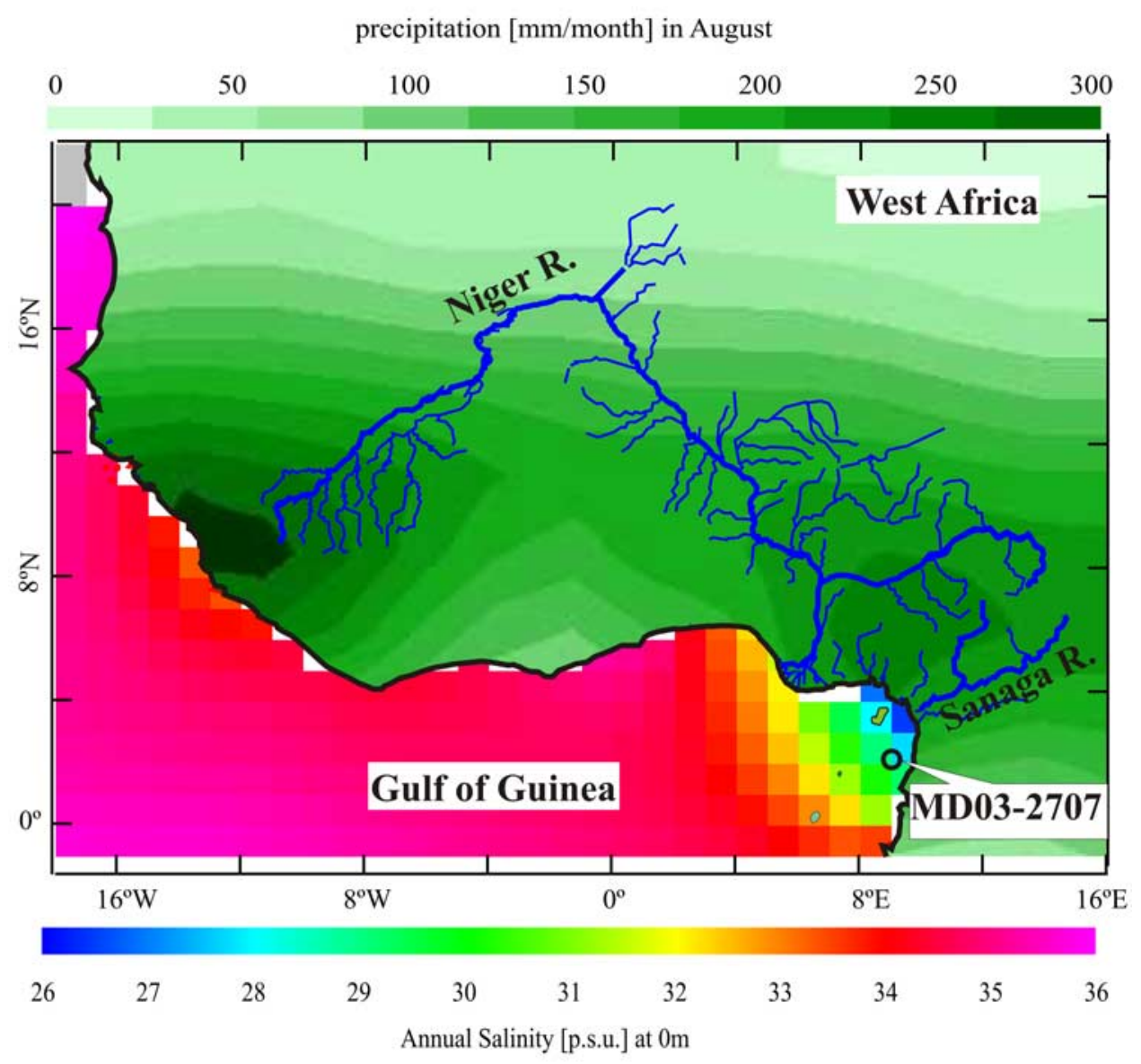

Figure 1. Map showing the location of the MD03-2707 core site in the Gulf of Guinea, annual sea surface salinity [Levitus, 1994], and monsoon precipitation in August over the continent [Janowiak and Xie, 1999].

$\left(\mathrm{SSS}=-7.47 *(\mathrm{Ba} / \mathrm{Ca})_{\text {foram }}+37.45, \mathrm{r}^{2}=0.98\right.$; error estimate(0.41 psu) (see AM). The Ba/Ca-based SSS estimates, however, should be regarded as first order estimates as $\mathrm{Ba} / \mathrm{Ca}_{\text {seawater-SSS relationship from the Gulf of Guinea is }}$ not yet available.

\section{Results}

[5] $\mathrm{Ba} / \mathrm{Ca}$-based SSS estimates of the core top material ( 360-500 yr BP) vary between 29 and $30 \mathrm{psu}$, which is close to the modern annual mean SSS (29 psu) in the upper $25 \mathrm{~m}$ of the water column. As suggested by the $\mathrm{Ba} / \mathrm{Ca}$ record, SSS levels similar to modern conditions were present only during the latest Holocene after a gradual decline in river runoff and monsoonal precipitation that started about 5,100 yr BP. Centennial-scale West African climate oscillations, as suggested by the $\mathrm{Ba} / \mathrm{Ca}$ record (Figure 2), are not clearly reflected in the $\delta^{18} \mathrm{O}$ record. We speculate that centennial-scale changes in monsoonal precipitation were accompanied by changes in moisture sources and hence the isotopic composition of rainfall, leading to changes in the isotope composition of riverine runoff. Such changes may have obscured the $\delta^{18} \mathrm{O}$ signal relative to that of $\mathrm{Ba} / \mathrm{Ca}$. At longer time scales, however, $\mathrm{Ba} / \mathrm{Ca}$ and $\delta^{18} \mathrm{O}$ follow summer insolation and offshore SST, suggesting that they are the dominant control on riverine runoff as recorded by both proxies.
[6] Mg/Ca-based SST estimates suggest relatively warm conditions during the early and mid Holocene, with mean SST $27.3 \pm 0.7^{\circ} \mathrm{C}(1 \mathrm{SD})$. The late Holocene is characterized by declining SSTs, with mean SST of $25.6 \pm 0.4^{\circ} \mathrm{C}$ in the core top material $(\sim 360-500 \mathrm{yr} \mathrm{BP})$. The core top values match the modern annual mean temperature at a water depth of $25-30 \mathrm{~m}$ and temperature at the upper $25 \mathrm{~m}$ of the water column from July to October. The modern SST at $0 \mathrm{~m}$ level is $27.5^{\circ} \mathrm{C}$ [Levitus, 1994] which is higher by $\sim 2{ }^{\circ} \mathrm{C}$ than the core top values. There are two mutually nonexclusive possibilities that may explain this deviation: (i) $\mathrm{Mg} / \mathrm{Ca} \mathrm{SST}$ estimates in the Gulf of Guinea record may be weighted towards summer SST or reflect calcification temperature at water depth of $\sim 25-30 \mathrm{~m}$; or (ii) the low salinity of surface waters leads to lower-than-expected foraminiferal $\mathrm{Mg} / \mathrm{Ca}$ at this site. We estimate that the low salinity in the Golf of Guinea could depress G. ruber $\mathrm{Mg} / \mathrm{Ca}$ by up to $25 \%$ relative to $\mathrm{S}=35 \mathrm{psu}$, and speculate that the salinity minimum of 25 in the early Holocene, as determined from $\mathrm{Ba} / \mathrm{Ca}$, could have further depressed $\mathrm{Mg} / \mathrm{Ca}$ and hence caused it to underestimate the recorded SST maximum at this time (see AM).

[7] On multi-centennial and centennial time scales, the MD03-2707 record reveals that the early and mid Holocene experienced numerous climate fluctuations. In order to statistically evaluate the time and frequency localization of the variability in $\mathrm{Ba} / \mathrm{Ca}, \mathrm{SST}$, and $\delta^{18} \mathrm{O}$ time series, we 


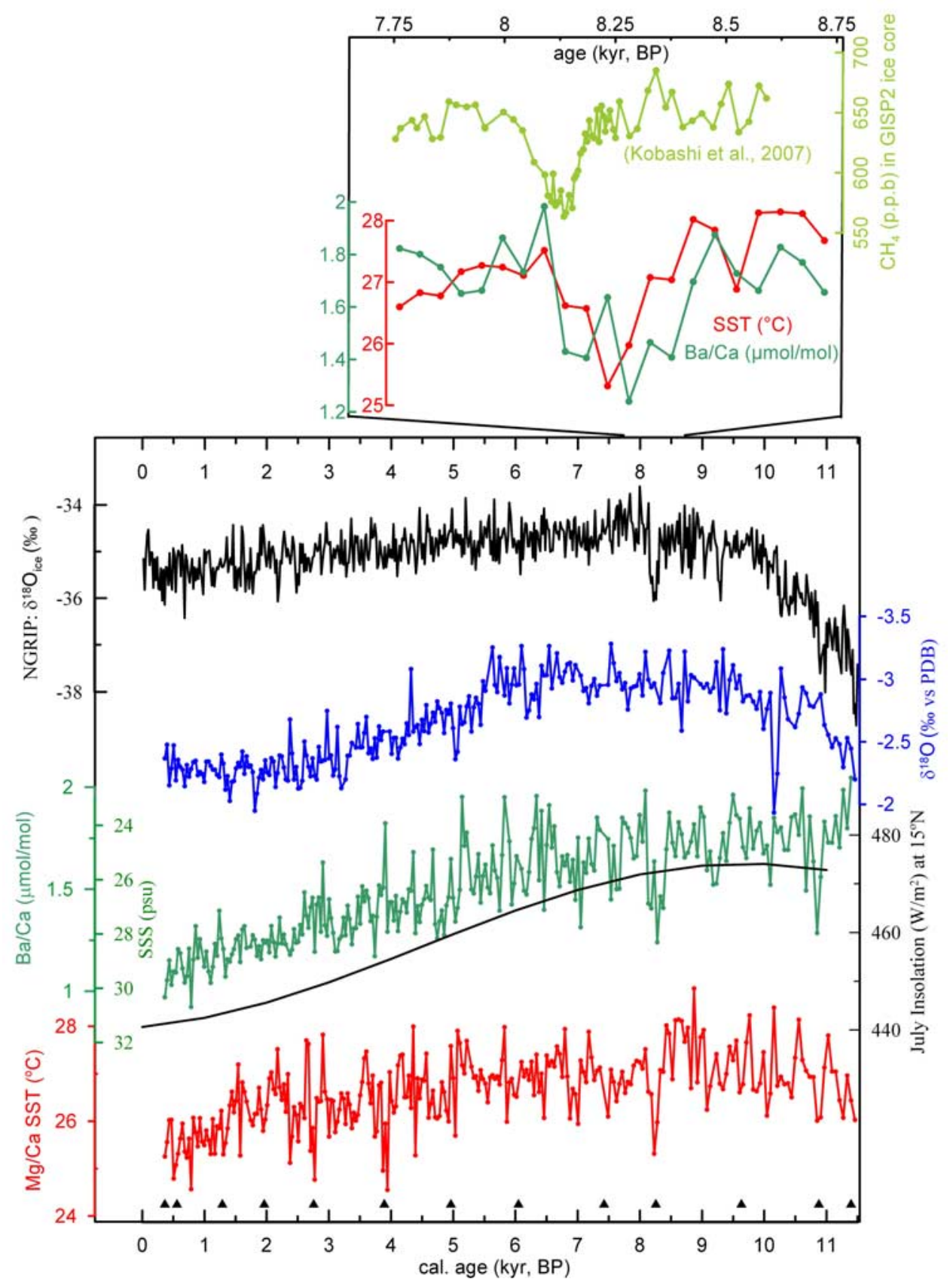

Figure 2. WAM and EEA thermal conditions during the Holocene in comparison with air temperature conditions over Greenland. The NGRIP $\delta^{18} \mathrm{O}_{\text {ice }}$ record [NGRIP members, 2004] is compared with $\delta^{18} \mathrm{O}, \mathrm{Ba} / \mathrm{Ca}$ and $\mathrm{Ba} / \mathrm{Ca}$-based SSS estimates, and Mg/Ca-based SST estimates in the MD03-2707 record. Triangles along the lower $\mathrm{x}$-axis indicate radiocarbon-based age control points. The inset shows a blow-up of $\mathrm{Ba} / \mathrm{Ca}$ and SST estimates over the time interval between 7.75 and $8.75 \mathrm{kyr}$ BP (the " $8.2 \mathrm{kyr}$ " event), in comparison with the timing of atmospheric methane decrease [Kobashi et al., 2007].

conducted wavelet spectrum analyses and cross correlation analyses (Figure 3 and auxiliary material). Wavelet spectrum analysis of the $\mathrm{Ba} / \mathrm{Ca}$ time series reveals that significant millennial-scale climate fluctuations are focused between $\sim 11,000$ and $\sim 7,000$ yr BP (Figure 3), with periods of about $500-1500$ years. High $\mathrm{Ba} / \mathrm{Ca}$ is punctuated by several centennial-scale sharp declines in $\mathrm{Ba} / \mathrm{Ca}$, suggesting that wet West African climate in the early and mid Holocene was repeatedly interrupted by rapidly decreasing precipitation. The most-prominent drops in $\mathrm{Ba} / \mathrm{Ca}$ occurred at $\sim 11,000-10,780,9,450-9,150$, and $8,430-8,140$ yr BP, suggesting an abrupt decline of riverine runoff and precipitation over the monsoon areas at these times. The early Holocene centennial-scale drops in monsoon precipitation correlate or overlap with the timing of air temperature cooling over Greenland [NGRIP members, 2004], fresh water fluxes into the North Atlantic [Barber et al., 1999; Clark et al., 2001], and climate deterioration in NW Europe 


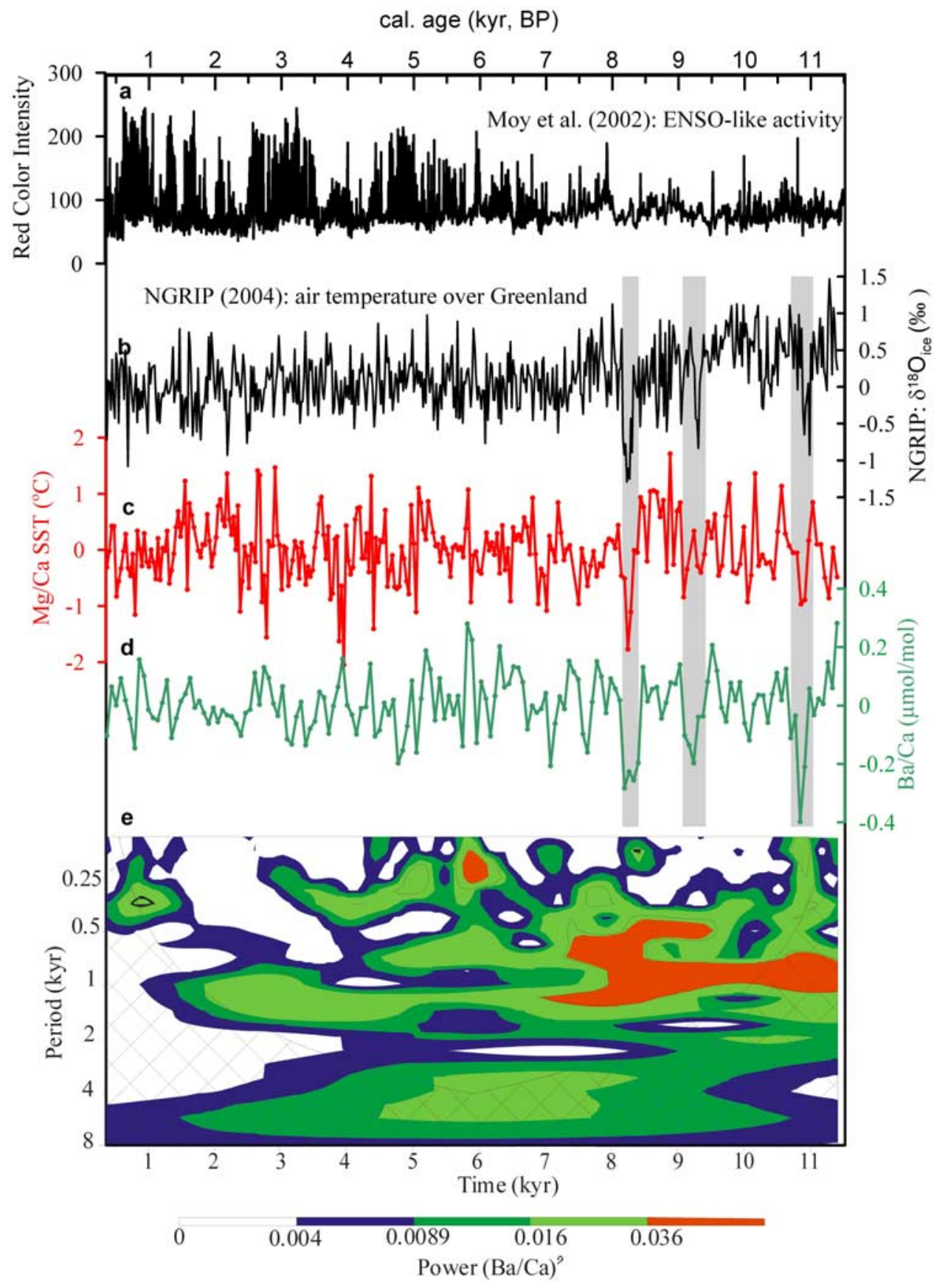

Figure 3. WAM and EEA thermal conditions during the Holocene compared with ENSO-like activity in the tropical Pacific climate realm [Moy et al., 2002] and air temperature conditions over Greenland. (a) Red colour intensity record from Peruan lake sediment core [Moy et al., 2002] and (b) detrended NGRIP $\delta^{18} \mathrm{O}_{\text {ice }}$ record [NGRIP members, 2004] are compared with (c) detrended $\mathrm{Mg} / \mathrm{Ca}$-based SST and (d) detrended and evenly spaced (70 years) Ba/Ca in the MD03-2707 record. Detrending of the long-term trend in the NGRIP and the Gulf of Guinea records is calculated using polynomial equations. Grey bars indicate intervals of WAM decline and EEA SST cooling that correlate with climate deterioration in northern high latitude. Also shown is (e) the wavelet power spectrum of the $\mathrm{Ba} / \mathrm{Ca}$ using online available software http:// ion.researchsystems.com/IONScript/wavelet/ [Torrence and Compo, 1998]). We used Morlet wavelet with wave number of 6 , start scale of 2 , and scale width of 0.25 . Black contour is the $10 \%$ significance level, using a red-noise background spectrum.

[Nesje et al., 2003]. At $\sim 11,000-10,780 \mathrm{yr} \mathrm{BP,} \mathrm{Ba/Ca} \mathrm{and}$ $\mathrm{Mg} / \mathrm{Ca}$-based SST estimates suggest a decline in riverine runoff and an EEA sea surface cooling, respectively. This low latitude hydrological and thermal event coincides, within age model uncertainty $( \pm 150 \mathrm{yr})$, with the timing of the Preboreal Oscillation (PBO) in the NGRIP $\delta^{18} \mathrm{O}$ record $(\sim 11,000-10,870$ yr BP). Marine and terrestrial records from the North Atlantic and Northwest Europe [Bond et al., 1997; Nesje et al., 2003] assign the PBO to about $11,300-10,750 \mathrm{yr} \mathrm{BP}$, which is also close to the 
timing of decreased riverine runoff and SST in the Gulf of Guinea record. According to the Gulf of Guinea $\mathrm{Ba} / \mathrm{Ca}$ record, a significant drop in riverine runoff occurred again at $~ 9,450-9,100 \mathrm{yr}$ BP, which is coincident with an air temperature cooling in the NGRIP record and cold SST in the North Atlantic [Bond et al., 1997].

[8] The most distinct early Holocene WAM event occurred between 8,430 and 8,140 yr $\mathrm{BP}$. $\mathrm{Ba} / \mathrm{Ca}$ declines sharply from $1.7 \mu \mathrm{mol} / \mathrm{mol}$ at $\sim 8,430 \mathrm{yr}$ BP to $1.4 \mu \mathrm{mol} /$ mol at $\sim 8,380 \mathrm{yr} B P$, suggesting a sharp decline of riverine runoff in the WAM area which persisted for $\sim 240$ years. After this events, $\mathrm{Ba} / \mathrm{Ca}$ increases abruptly from $1.4 \mu \mathrm{mol} /$ $\mathrm{mol}$ at $\sim 8,140 \mathrm{yr}$ BP to $1.8 \mu \mathrm{mol} / \mathrm{mol}$ at $\sim 8,090 \mathrm{yr} \mathrm{BP}$, suggesting re-establishment of high riverine runoff within $\sim 50$ years. The abrupt weakening of the WAM between $\sim 8,430-8,140$ yr BP was accompanied by a synchronous decrease of $1.7 \pm 0.6^{\circ} \mathrm{C}$ in SST (Figure 2). The timing of this event corresponds with wide-spread climate deterioration in the northern high and mid latitudes [Alley and Agustsdottir, 2005; Rohling and Pälike, 2005] and correlates well, within age model uncertainty of \pm 150 years, with the timing of air temperature cooling over Greenland. The timing of reduced atmospheric methane concentration associated with the " $8.2 \mathrm{kyr}$ event" in the GISP2 ice core record is estimated at between 8,175 and 8,025 yrs BP, with an uncertainty of \pm 30 yrs [Kobashi et al., 2007]. According to the chronologies of the two records, the onset of West African precipitation decline pre-dated the atmospheric methane decline by $250 \pm 150$ years (Figure 2). This suggests that either low latitude climate deterioration started earlier with no significant influence on atmospheric methane, or, assuming that monsoon weakening and decline in atmospheric methane are causally linked and temporally coincident, the deviation in timing is related to uncertainties in one or both age models. Given the relatively large uncertainties in the radiocarbon-based age model for the Gulf of Guinea record, and, to lesser degree, uncertainties in the ice core gas age model, we favor the hypothesis that WAM precipitation decline and changes in atmospheric methane were simultaneous events.

\section{Discussion}

[9] Early Holocene WAM and EEA SST changes reveal strong correlations with northern high latitude climate oscillation [NGRIP members, 2004] and episodic freshwater outbursts into the North Atlantic [Barber et al., 1999; Clark et al., 2001]. This observation has several implications. First, early Holocene climate instabilities, originally documented in the northern high latitudes, also left strong oceanic and atmospheric imprints in the low latitudes. Second, weakening of West African summer monsoon precipitation in concert with these instabilities indicates that these hemisphere scale-events were not confined to the winter, as appears to be the case during glacial episodes [Denton et al., 2005]. Third, in contrast to the last deglaciation, when WAM followed northern high climate fluctuations and was decoupled from EEA SST [Weldeab et al., 2007], early Holocene WAM deterioration occurred in synchrony with EEA SST cooling.

[10] Centennial-scale variability in the $\mathrm{Ba} / \mathrm{Ca}$ record persisted throughout the middle Holocene (Figures 2 and
3). Positive excursions of $\mathrm{Ba} / \mathrm{Ca}$ occurred at $\sim 6,700-6,120$, $6,000-5,800$, and $5,250-5,100$ yr BP, with higher $\mathrm{Ba} / \mathrm{Ca}$ than the average trend, suggesting episodic strengthening of the monsoon system. In contrast to the early Holocene record, middle Holocene oscillations of riverine runoff, as suggested by $\mathrm{Ba} / \mathrm{Ca}$, were not matched by changes in air temperature over Greenland. This is most likely due to the reduction of northern hemsiphere ice sheets from intermediate size during the early Holocene to their minimum size after $\sim 7,000$ yr BP.

[11] Throughout the entire Holocene, there is no clear correspondence between changes in WAM precipitation and variability of the ${ }^{10} \mathrm{Be}$ record [Finkel and Nishiizumi, 1997], a proxy for short-termed variability in solar activity (see discussion by Field et al. [2006] for the constraints in applying centennial-scale ${ }^{10} \mathrm{Be}$ to solar activity reconstructions). Several modeling studies [Balas et al., 2007; Camberlin et al., 2001] suggest that EEA SSTs exert significant control on WAM precipitation. This is largely corroborated by our findings and previous studies [Weldeab et al., 2005]; however, not all centennial-scale changes in monsoon precipitation are matched by significant changes in the EEA SST records during the middle and late Holocene (Figure 2), indicating a complex interplay of several factors modulating the monsoon behaviour [Balas et al., 2007]. Under modern conditions, one of these factors is the El Niño Southern Oscillation (ENSO) [Balas et al., 2007; Camberlin et al., 2001]. Although the resolution of the $\mathrm{Ba} / \mathrm{Ca}$ record is probably insufficient to confidently unravel a possible Holocene linkage between the WAM and ENSO, it is worth noting that there is a generally opposite trend on the millennial-scale, with weak or absent ENSO-like activity in the equatorial Pacific climate realm [Moy et al., 2002] and wet and unstable WAM during the early and mid Holocene (Figure 3). Quiescent ENSO dynamics [Moy et al., 2002] and expansion of WAM area along with prolonged seasonal rainfall [Kutzbach and Liu, 1997; Weldeab et al., 2007] during the early Holocene is consistent with a northward shift of the intertropical convergence zone (ITCZ) in response to strong late summer northern hemisphere insolation [Cane, 2005; Clement et al., 2001; Kutzbach and Liu, 1997]. Centennial-scale drops in early Holocene monsoon rainfall have, however, no clear counterparts in the ENSO record [Moy et al., 2002]. Conversely, enhanced ENSO-like activity in the late Holocene, as suggested by Moy et al [2002], is paralleled by stable West African precipitation, suggesting that any linkage between the WAM and ENSO during the Holocene was sporadic (Figure 3). Therefore, Holocene WAM precipitation appears to be predominantly controlled by northern hemisphere low latitude insolation, northern high latitude climate oscillations, and tropical Atlantic SST variation.

\section{Conclusion}

[12] This study demonstrates that WAM precipitation and riverine runoff, as reconstructed from planktic foraminiferal $\mathrm{Ba} / \mathrm{Ca}$ in a Gulf of Guinea sediment core, experienced centennial to millennial scale fluctuations during the Holocene. Early Holocene rapid changes in WAM precipitation show strong linkages to high latitude northern hemisphere climate shifts and fresh water outbursts into the North 
Atlantic, with the " $8.2 \mathrm{kyr}$ " event especially prominent. This connection was likely caused by synchronous latitudinal shifts of the polar front and the ITCZ. EEA surface waters cooled when monsoon precipitation declined, suggesting an additional low latitude control on monsoon precipitation during the $8.2 \mathrm{kyr}$ event. On orbital timescales, both WAM precipitation and runoff and EEA SSTs decline continuously over the course of the Holocene, as expected from the influence of declining boreal midsummer insolation. In contrast to the early Holocene, the strength of the WAM during the middle and late Holocene was not linked to northern high latitude climate conditions, presumably because of the diminished size of northern hemisphere ice sheets after $\sim 7,000$ yr BP.

[13] Acknowledgments. We thank Holger Kuhlmann and two anonymous reviewers for their comments and suggestion on an earlier version of the manuscript. S. Weldeab has been supported by the DFG (WE 2686/2-1) and D. W. Lea by NSF OCE0317611 and OCE0502609. Data presented in this study are available at http://www.ncdc.noaa.gov/paleo/ pubs/weldeab2007.

\section{References}

Alley, R. B., and A. M. Agustsdottir (2005), The 8k event: Cause and consequences of a major Holocene abrupt climate change, Quat. Sci. Rev., 24, 1123-1149.

Balas, N., S. E. Nicholson, and D. Klotter (2007), The relationship of rainfall variability in west central Africa to sea-surface temperature fluctuations, Int. J. Climatol., 27, 1335-1349.

Barber, D. C., et al. (1999), Forcing of the cold event of 8,200 years ago by catastrophic drainage of Laurentide lakes, Nature, 400, 344-348.

Bond, G., W. Showers, M. Cheseby, R. Lotti, P. Almasi, P. deMenocal, P. Priore, H. Cullen, I. Hajdas, and G. Bonani (1997), A pervasive millennial-scale cycle in North Atlantic Holocene and glacial climates, Science, 278, 1257-1266.

Camberlin, P., S. Janicot, and I. Poccard (2001), Seasonality and atmospheric dynamics of the teleconnection between African rainfall and tropical SST: Atlantic vs ENSO, Int. J. Climatol., 21, 973-1005.

Cane, M. A. (2005), The evolution of El Nino, past and future, Earth Planet. Sci. Lett., 230, 227-240.

Clark, P. U., S. J. Marshall, G. K. C. Clarke, S. W. Hostetler, J. M. Licciardi, and J. T. Teller (2001), Freshwater forcing of abrupt climate change during the last glaciation, Science, 293, 283-287.

Clement, A. C., M. A. Cane, and R. Seager (2001), An orbitally driven tropical source for abrupt climate change, J. Clim., 14, 2369-2375.

deMenocal, P., J. Ortiz, T. Guilderson, and M. Sarnthein (2000), Coherent high- and low-latitude variability during the Holocene warm period, Science, 288, 2198-2202.

Denton, G. H., R. B. Alley, G. C. Comer, and W. S. Broecker (2005), The role of seasonality in abrupt climate change, Quat. Sci. Rev., 24, 11591182 .

Field, C. V., G. A. Schmidt, D. Koch, and C. Salyk (2006), Modeling production and climate-related impacts on ${ }^{10} \mathrm{Be}$ concentration in ice cores, J. Geophys. Res., 111, D15107, doi:10.1029/2005JD006410.
Finkel, R. C., and K. Nishiizumi (1997), Beryllium 10 concentrations in the Greenland Ice Sheet Project 2 ice core from 3-40 ka, J. Geophys. Res. 102, 26,699-26,706.

Janowiak, J. E., and P. Xie (1999), CAMS_OPI: A global satellite-rain gauge merged product for real-time precipitation monitoring applications, J. Clim., 12, 3335-3342.

Kobashi, T., J. P. Severinghaus, E. J. Brook, J.-M. Barnola, and A. M. Grachev (2007), Precise timing and characterization of abrupt climate change 8200 years ago from air trapped in polar ice, Quat. Sci. Rev, 26, $1212-1222$.

Kuhlmann, H., H. Meggers, T. Freudenthal, and G. Wefer (2004), The transition of the monsoonal and the N Atlantic climate system off NW Africa during the Holocene, Geophys. Res. Lett., 31, L22204, doi:10.1029/2004GL021267.

Kutzbach, J. E., and Z. Liu (1997), Response of the African monsoon to orbital forcing and ocean feedbacks in the Middle Holocene, Science, $278,440-443$.

Lea, D. W., and H. Spero (1994), Assessing the reliability of the paleochemical tracers: Barium uptake in the shells of planktonic foraminifera, Paleoceanography, 9, 445-452.

Levitus, S. (1994), World Ocean Atlas 1994, vol. 4, Temperature, NOAA Atlas NESDIS 3, NOAA, Silver Spring, Md.

Lezine, A.-M., and J.-P. Cazet (2005), High-resolution pollen record from core KW31, Gulf of Guinea, documents the history of the lowland forests of West Equatorial Africa since 40,000 yr ago, Quat. Res., 64, 432-443.

Moy, C. M., G. O. Seltzer, D. T. Rodbell, and D. M. Anderson (2002), Variability of El Nino/Southern Oscillation activity at millennial timescales during the Holocene epoch, Nature, 420, 162-165.

Nesje, A., S. O. Dahl, and J. Bakke (2003), Were abrupt Lateglacial and early-Holocene climate change in northwest Europe linked to changes to freshwater outbursts to the North Atlantic and Arctic Oceans?, Holocene, 14, 299-310.

NGRIP Members (2004), High-resolution record of Northern Hemisphere climate extending into the last interglacial period, Nature, 431, 147-151.

Rohling, E. J., and H. Pälike (2005), Centennial-scale climate cooling with a sudden cold event around 8,200 years ago, Nature, 434, 975-979.

Shanahan, T. M., J. T. Overpeck, C. W. Wheeler, J. W. Beck, J. S. Pigati, M. R. Talbot, C. A. Scholz, J. Peck, and J. W. King (2006), Paleoclimatic variations in West Africa from a record of late Pleistocene and Holocene lake level stands of Lake Bosumtwi, Ghana, Palaeogeogr. Palaeoclimatol. Palaeoecol., 242, 287-302.

Torrence, C., and G. P. Compo (1998), A practical guide to wavelet analysis, Bull. Am. Meteorol. Soc., 79, 61-78.

Weldeab, S., R. R. Schneider, M. Kölling, and G. Wefer (2005), Holocene African droughts relate to east-equatorial Atlantic cooling, Geology, 33, 981-984, doi:910.1130/G21874.21871.

Weldeab, S., D. W. Lea, R. R. Schneider, and N. Andersen (2007), 155,000 years of West African monsoon and ocean thermal evolution, Science, 316, $1303-1307$.

N. Andersen, Leibniz-Labor für Altersbestimmung und Isotopenforschung, Universität Kiel, Kiel D-24118, Germany.

D. W. Lea, Department of Earth Science and Marine Science Institute, University of California, Santa Barbara, CA 93106-9630, USA.

S. Weldeab, IFM-GEOMAR, Kiel D-24148, Germany. (sweldeab@ ifm-geomar.de)

R. R. Schneider, Institut für Geowissenschaften, Universität Kiel, Kiel D24118, Germany. 